\title{
EVALUATION OF THE SURFACE INTEGRITY IN THE MILLING OF A MAGNESIUM ALLOY USING AN ARTIFICIAL NEURAL NETWORK AND A GENETIC ALGORITHM
}

\author{
OVREDNOTENJE INTEGRITETE POVRŠINE PO MEHANSKI \\ OBDELAVI MAGNEZIJEVE ZLITINE Z UPORABO UMETNE \\ NEVRONSKE MREŽE IN GENETSKEGA ALGORITMA
}

\author{
Madhesan Pradeepkumar', Rajamanickam Venkatesan², Varatharajan Kaviarasan' \\ ${ }^{1}$ Sona College of Technology, Department of Mechanical Engineering, Salem, Tamil Nadu, 636005, India \\ ${ }^{2}$ Kumaraguru College of Technology, Department of Mechatronics Engineering, Coimbatore, Tamil Nadu, 641049, India \\ pradeepkumar@sonatech.ac.in \\ Prejem rokopisa - received: 2017-11-23; sprejem za objavo - accepted for publication: 2018-01-09
}

\begin{abstract}
Magnesium alloys are advanced, light materials used widely in industries and milling is one of the material removal processes that are extensively used. In this present study, the experimental work has been carried out based on a Box-Behnken design by mainly considering three factors, i.e., cutting speed, feed, and depth of cut. The first part of in this study, the effects of Response Surface methodology (RSM) and Artificial Neural Network (ANN) models were evaluated and compared. The RSM and ANN models provide the average error of $2.40 \%$ and $1.52 \%$, respectively, it recommends that ANN is a more efficient methodology for the prediction of the optimal output response than RSM. The predicted model has been coupled with evolutionary optimization technique genetic algorithm (GA) to determine the optimum cutting parameters to attain the minimal surface roughness with respect to the wide ranges of machining parameters and GA suggest the surface roughness of $1.0926 \mu \mathrm{m}$ with the optimized machining parameters. The evaluation of these observations proves that the proposed methods are capable of determining the optimum machining parameters for modern materials.
\end{abstract}

Keywords: artificial neural network, genetic algorithm, magnesium alloy, milling, optimization

Zlitine na osnovi magnezija $(\mathrm{Mg})$ so napreden lahek material, ki se pogosto uporablja v različnih vejah industrije. Njegova mehanska obdelava z rezkanjem je ena od najpogostejših metod odstranjevanja materiala za dokončno oblikovanje različnih industrijskih izdelkov. V predstavljeni študiji avtorji opisujejo eksperimentalno delo izvedeno na osnovi Box-Behnkenovega dizajna $\mathrm{z}$ upoštevanjem treh faktorjev: rezalne hitrosti, pomika in globine reza. V prvem delu te študije so avtorji ovrednotili in primerjali učinke dveh uporabljenih modelov: metodologije reakcije površine (RSM; angl.: Response Surface Methodology) in umetne nevronske mreže (ANN, angl: Artificial Neural Network). RSM in ANN modela sta predvidela povprečno 2,40 \% oz. $1,52 \%$ napako. To pomeni, da je ANN učinkovitejša methodologija za napoved optimalne (reakcije) storilnosti. Model za prognozo so avtorji združili z evolucijsko optimizacijsko tehniko genetskih algoritmov (GA) in na ta način določili optimalne rezalne parametre za dosego minimalne površinske hrapavosti v območju dokaj široko izbranih parametrov mehanske obdelave. GA napoveduje površinsko hrapavost $1.0926 \mu \mathrm{m}$ pri optimiziranih parametrih mehanske obdelave. Ovrednotenje teh opazovanj je potrdilo da, je s predlaganimi metodami možno določiti optimalne parametre mehanske obdelave modernih materialov.

Ključne besede: umetna nevronska mreža, genetski algoritem, zlitina na osnovi Mg, rezkanje, optimizacija

\section{INTRODUCTION}

Magnesium alloys are new composite materials and nowadays used widely in industries due to their excellent strength-to-weight ratio. ${ }^{1}$ According to that many aircraft and automobile industries focus on making products in magnesium alloys. Surface roughness has become a significant factor in terms of quality and economy characteristics. $^{2}$ In modern industries, CNC machines are widely used to produce complicated shapes on advanced materials with high quality and accuracy. An appropriate choice of machining parameters for the CNC milling greatly depends on the operator's expertise and manufacturer guidelines. ${ }^{3-4}$ Hence, machining parameters for newer materials need to be optimized by experimental methods.
K. Shi et al. ${ }^{5}$ have studied the process parameter effects on the milling of magnesium alloys using Taguchi methodology and grey rational analysis. They reported that the feed rate is the most significant factor affecting the surface integrity and they found the optimum combination of process parameters through the grey rational technique. They suggest the combination of both methodologies were an effective method to obtain the desired surface quality for the milling process. N. Haq et al. ${ }^{6}$ studied the effects of drilling parameters Al-SiC (10p) MMC on LM25 alloy using grey relational analysis. Cutting speed, feed rate, and point angle were taken as the cutting parameters. Surface roughness, cutting force and torque were determined by experiments. Taguchi's method of orthogonal array $\mathrm{L}_{9}$ was followed to the experimental process. They concluded that point angle is the most significant machining 
parameter for affecting the surface roughness, followed by cutting speed and feed. A. M. Zain et al. ${ }^{7}$ conducted milling experiments with two-level factorial design and they studied the surface roughness effects on the milling process with respect to the high cutting speed, low feed rate and rake angle of machining parameters using ANN. J. Kopac et al. ${ }^{8}$ predicted the optimum surface roughness and material removal rate in the milling of an Al alloy with respect to the flank milling parameters and they obtained an optimal combination in the integration of Taguchi and Grey relational analysis. J. A. Ghani et al. ${ }^{9}$ applied the Taguchi methodology and ANOVA to optimize the cutting parameters, i.e., cutting speed, feed rate and depth of cut in end milling of hardened steel AISI H13 with TiN-coated P10 carbide insert tool, and they recommend the optimal combination of parameters as higher cutting speed, lower feed rate and lower depth of cut would produce a good surface finish with low resultant cutting force. J. S. Pang et al. ${ }^{10}$ evaluated the depth of cut, cutting speed and feed rate machining parameters on the milling of the halloysite nanotubes (HNTs) with aluminum reinforced epoxy hybrid composite material under dry condition to predict the optimal machining parameters to attain the best surface finish using the Taguchi method. E. Kuram and B. Ozcelik $^{11}$ evaluated multi-objective optimization methodology using Taguchi based grey relational analysis for the micro-milling of Al 7075 material with a ball-nose end mill. They investigated the effects of spindle speed, feed per tooth and depth of cut on the tool wear, force and surface roughness and finally, the responses were optimized using grey relational analysis.

From the literature survey, it is seen that the most of the researchers have carried out the process parameter optimization using Taguchi, RSM and ANN tools on different materials; however, there is very little research on advanced materials like the magnesium AZ91D alloy. This paper deals with the optimization of the end milling process parameters through evolutionary optimization techniques such as RSM, ANN and GA methodologies applied to an advanced material of magnesium alloy AZ91D to obtain a better surface finish.

\section{EXPERIMENTAL PART}

In this experimental work, the modern material magnesium AZ91D alloy was taken for evaluating the optimum machining parameters in the end milling process to achieve the minimal surface finish. The milling process was done as per the recommendation of RSM Box-Behnken design of experiments and this work were analyzed, compared with RSM and ANN. The anticipated model coupled with the evolutionary optimization technique GA to attain the better surface finish with the diversity of machining parameters and the proposed experimental methodology shown in Figure 1.

\subsection{End milling process}

The work material with a size of $70 \mathrm{~mm} \times 70 \mathrm{~mm} \times$ $10 \mathrm{~mm}$ of length, height and width, respectively, were taken and high-speed steel tool has been utilized for machining process under dry conditions. The cutting speed $(N)$ feed rate $(f)$ and depth of cut $(a p)$ were considered as cutting parameters for this experiment work. The 15 experiments were carried out based on the recommendation of Box-Behnken design of experiment by the interaction of three machining parameters with three levels. The output response surface roughness is

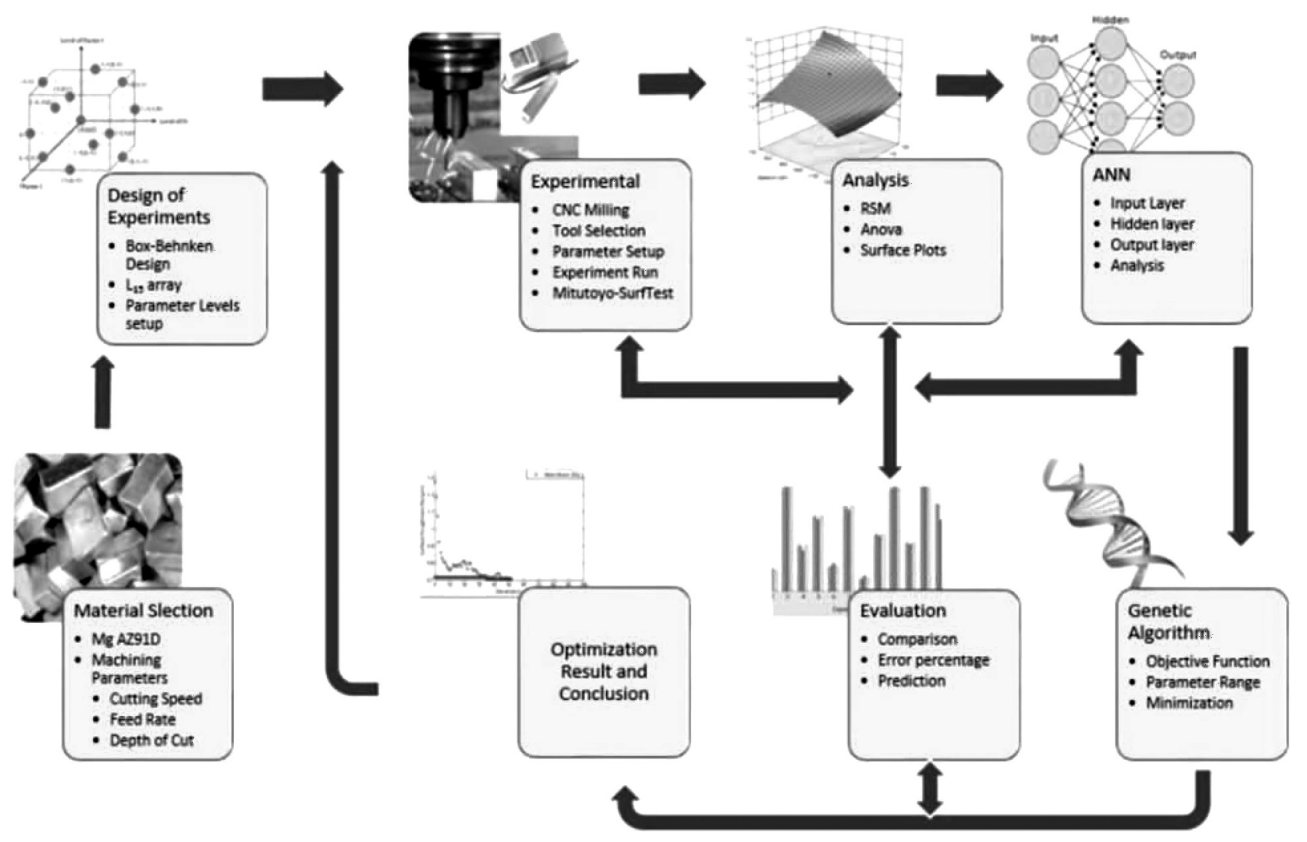

Figure 1: Proposed experimental methodology 
measured with use of Mitutoyo Surftest 211 instrument corresponding to the experimental run and reported in Table 1.

Table 1: Box-Behnken design of experiments with experimental values and predicted values

\begin{tabular}{|c|c|c|c|c|c|c|}
\hline $\begin{array}{c}\text { Expe- } \\
\text { riment } \\
\text { run }\end{array}$ & $\begin{array}{c}N \\
\left(\mathrm{~min}^{-1}\right)\end{array}$ & $\begin{array}{c}f \\
(\mathrm{~mm} / \\
\mathrm{rev})\end{array}$ & $\begin{array}{c}\text { ap } \\
(\mathrm{mm})\end{array}$ & $\begin{array}{c}\text { Expe- } \\
\text { riment } \\
\text { actual }\end{array}$ & $\begin{array}{c}\text { RSM } \\
\text { pre- } \\
\text { dicted }\end{array}$ & $\begin{array}{c}\text { ANN } \\
\text { pre- } \\
\text { dicted }\end{array}$ \\
\hline 1 & 750 & 75 & 0.4 & 1.28 & 1.3225 & 1.271 \\
\hline 2 & 1250 & 75 & 0.4 & 1.2 & 1.1875 & 1.1712 \\
\hline 3 & 750 & 125 & 0.4 & 2.1 & 2.1125 & 2.0766 \\
\hline 4 & 1250 & 125 & 0.4 & 1.38 & 1.3375 & 1.3805 \\
\hline 5 & 750 & 100 & 0.3 & 1.62 & 1.5925 & 1.6221 \\
\hline 6 & 1250 & 100 & 0.3 & 1.2 & 1.2275 & 1.199 \\
\hline 7 & 750 & 100 & 0.5 & 1.7 & 1.6725 & 1.7032 \\
\hline 8 & 1250 & 100 & 0.5 & 1.1 & 1.1275 & 1.1112 \\
\hline 9 & 1000 & 75 & 0.3 & 1.47 & 1.455 & 1.4711 \\
\hline 10 & 1000 & 125 & 0.3 & 1.85 & 1.865 & 1.8508 \\
\hline 11 & 1000 & 75 & 0.5 & 1.4 & 1.385 & 1.4015 \\
\hline 12 & 1000 & 125 & 0.5 & 1.9 & 1.915 & 1.9004 \\
\hline 13 & 1000 & 100 & 0.4 & 1.72 & 1.59 & 1.6011 \\
\hline 14 & 1000 & 100 & 0.4 & 1.48 & 1.59 & 1.6011 \\
\hline 15 & 1000 & 100 & 0.4 & 1.57 & 1.59 & 1.6011 \\
\hline
\end{tabular}

\subsection{Response surface methodology (RSM)}

The RSM is an experimental modeling technique through which the relationship between control variables and responses are found. ${ }^{12,13}$ The objective of using RSM in this research is to investigate the effect of cutting speed, feed rate and depth of cut on the surface finish $\left(R_{\mathrm{a}}\right)$.

The response $Y=\psi(N, f, a p)$

The surface finish $R_{\mathrm{a}}=\psi(N, f, a p)$

The second-order RSM model for the present research is given by:

$$
Y=\alpha_{0}+\sum_{i=1}^{k} \beta_{i} X_{i}+\sum_{i=j}^{k} \beta_{i} X_{i} X_{j}+\sum_{i=1}^{K} \beta_{i i} X_{i}^{2}
$$

Where $a_{0}$ is the free term of the regression equation; $X_{1}, X_{2}, \ldots X_{\mathrm{n}}$ are variable terms, $\beta_{1}, \beta_{2}, \ldots, \beta_{\mathrm{k}}$ are the linear coefficient terms; $\beta_{11}, \beta_{22}, \ldots, \beta_{\mathrm{kk}}$ are the quadratic coefficient terms; and $\beta_{12}, \beta_{13}, \ldots \beta_{\mathrm{k}-1}$ are the interacting coefficient terms. ${ }^{14,15}$

\subsection{Artificial neural network (ANN)}

ANNs are inspired with the aid of the biological nervous system. It consists of a huge number of noticeably linked factors called neurons. To achieve the specific output target the neural network was trained by adjusting the values of the weights between neurons. In an artificial intelligence the network was trained based on the several input and target pairs, furthermore the network is adjusted based on an assessment of the output and the target till the network output suits the goal. ${ }^{16,17}$ The three machining parameters speed, feed, and depth of cut were used as an input layer with one hidden layer of eight neurons to attain one output layer as surface roughness. The neural network was trained by a random training data set and a feed-forward back-propagation algorithm was used for the train the network. The back propagation algorithm ${ }^{18,19}$ is works based on the method of gradient descent and it updates the mean square error values with respect to the target and training values by the iteration of weights. In this ANN model, the hidden layer and output layer activation functions were fixed as logsig and tansig, respectively, for the output response of the surface roughness. In terms of the ANN training function, learning functions were placed as traingdx and learngd, respectively. The developed neural network model was trained based on the parameters, training was carried out for 1000 iterations (epochs) and the predicted results for surface roughness are presented in Table 1.

\subsection{Genetic algorithm (GA)}

GA is an evolutionary optimization procedure to find the solutions for problems involving the application of principles of evolutionary biology. ${ }^{20,21}$ GAs use biologically inspired methods like genetic inheritance, natural selection, mutation, and crossover. The solution of an optimization with GA begins with a set of ability solutions or chromosomes inside the character of bit strings, which might be randomly selected. The entire set of these chromosomes incorporates a population and the chromosomes evolve for the duration of numerous iterations or generations. ${ }^{22,23}$ The GA optimization has been carried out with the use of MATLAB ${ }^{\circledR}$ software with the quadratic model Equation (4) has been utilized as an objective function. The procedures to conduct optimization process, the population size 200, 0.8 crossover probability, uniform distribution of mutation rate of 0.1 , the stall generation as 100 and the stopping criteria as best fitness were used. The ranges of the machining parameters, objective function were fixed as

$N_{\min } \leq N \leq N_{\max } ; f_{\min } \leq f \leq f_{\max }$ $a p_{\min } \leq a p \leq a p_{\max }$

Objective function $=$ Minimize $R_{\mathrm{a}}\left(N_{,}, f, a p\right)$

\section{RESULTS AND DISCUSSION}

\subsection{Main effects and the analysis of variance}

In this study the evaluation of the main effects of the machining parameters on the milling of magnesium alloy for surface roughness were shown in Figure 2. The main effect plot shows that the lower rate of speed gives highest surface roughness value and better surface finish can be achieved at a higher speed rate. In terms of feed rate, the plot realizes that minimal surface roughness is obtained at a lower rate of feed and while increasing feed rate, the surface roughness is increased predominately. In an analysis of the depth-of-cut parameter, it understands that the parameter is insignificant in this operation and 
there is minimal deviation occurring in the surface roughness in spite of increasing or decreasing depth of cut ranges. The effects plots recommend that the higher level of cutting speed, middle level of feed rate and a higher level of depth of cut provides smallest surface roughness value.

The main objective of the ANOVA is to notice which machining parameters significantly affect the quality characteristics. In this experimental work, the ANOVA Table 2 shows that the percentage contribution of the model and the error were 96.76 and 3.24, respectively, it realize that the experiment was done with significant machining parameters. From this the first order of feed rate and cutting speed has more contribution on surface roughness than the depth of cut and the percentages were 38.43 and 36.03, respectively. In terms of second-order interaction, the cutting speed has a higher contribution of $10.48 \%$ compared to other factors. The ANOVA suggests the feed rate has more contribution in end milling operation than the cutting speed, it means the slightest change of feed rate will affect the surface-roughness bound values. The adequacy of the model is investigated by the examination of residuals. The normal probability plots of the residuals versus the predicted response and Box-Behnken cubic model for the surface roughness values are shown in Figure $\mathbf{3}$ and it reveals that the residuals generally fall on a straight line, implying that the errors are distributed normally.

Table 2: Analysis of variance for surface roughness

\begin{tabular}{|c|c|c|c|c|c|}
\hline Source & DF & SS & MS & F & $\begin{array}{c}\text { Contri- } \\
\text { bution }\end{array}$ \\
\hline$N$ & 1 & 0.41405 & 0.414 & 55.58 & $36.02 \%$ \\
\hline$f$ & 1 & 0.44180 & 0.441 & 59.30 & $38.43 \%$ \\
\hline$a p$ & 1 & 0.00020 & 0.0002 & 0.03 & $0.02 \%$ \\
\hline$N^{*} N$ & 1 & 0.12048 & 0.1130 & 15.18 & $10.48 \%$ \\
\hline$f^{*} f$ & 1 & 0.02132 & 0.0207 & 2.79 & $1.85 \%$ \\
\hline$a p^{*} a p$ & 1 & 0.00037 & 0.0003 & 0.05 & $0.03 \%$ \\
\hline$N^{*} f$ & 1 & 0.10240 & 0.1024 & 13.74 & $8.91 \%$ \\
\hline$N^{*} a p$ & 1 & 0.00810 & 0.0081 & 1.09 & $0.70 \%$ \\
\hline$f^{*} a p$ & 1 & 0.00360 & 0.0036 & 0.48 & $0.31 \%$ \\
\hline Error & 5 & 0.03725 & 0.0074 & & $3.24 \%$ \\
\hline Total & 14 & 1.14957 & & & $100.00 \%$ \\
\hline
\end{tabular}

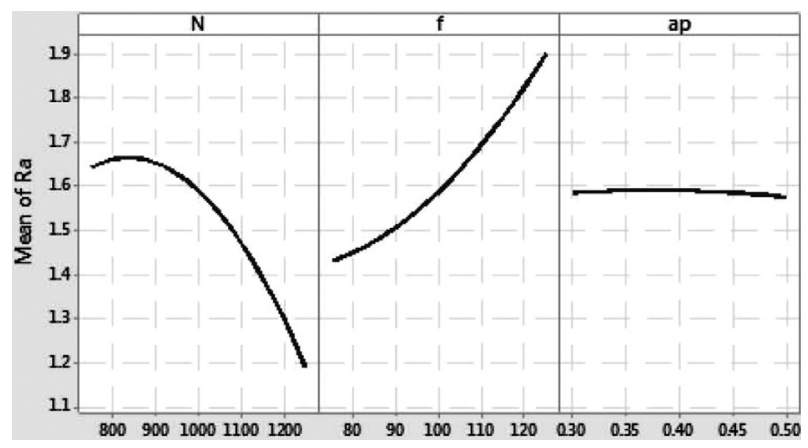

Figure 2: Main effect plots for surface roughness

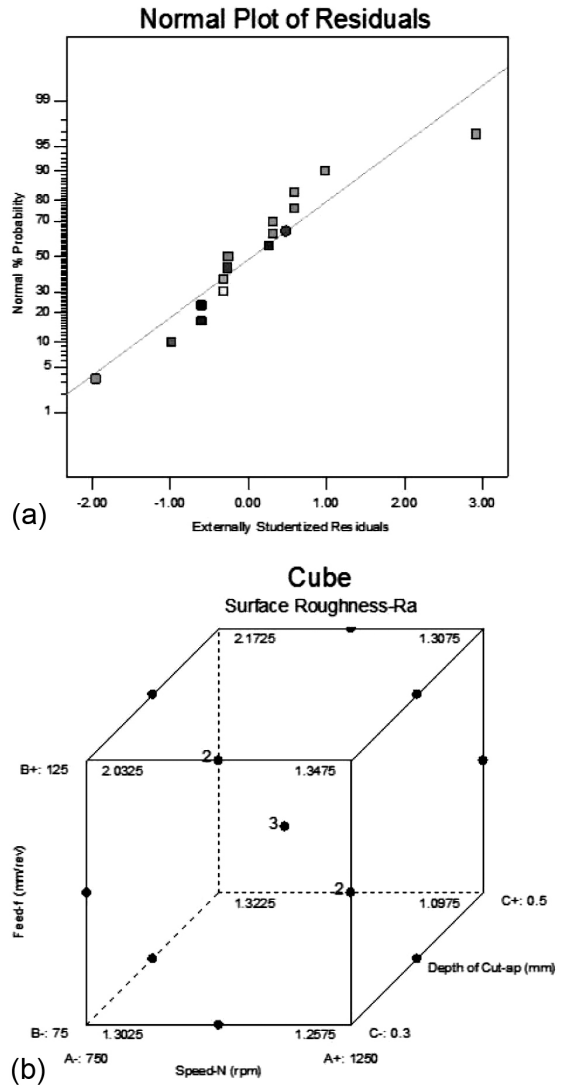

Figure 3: Normal plot and RSM Box-Behnken cubic design
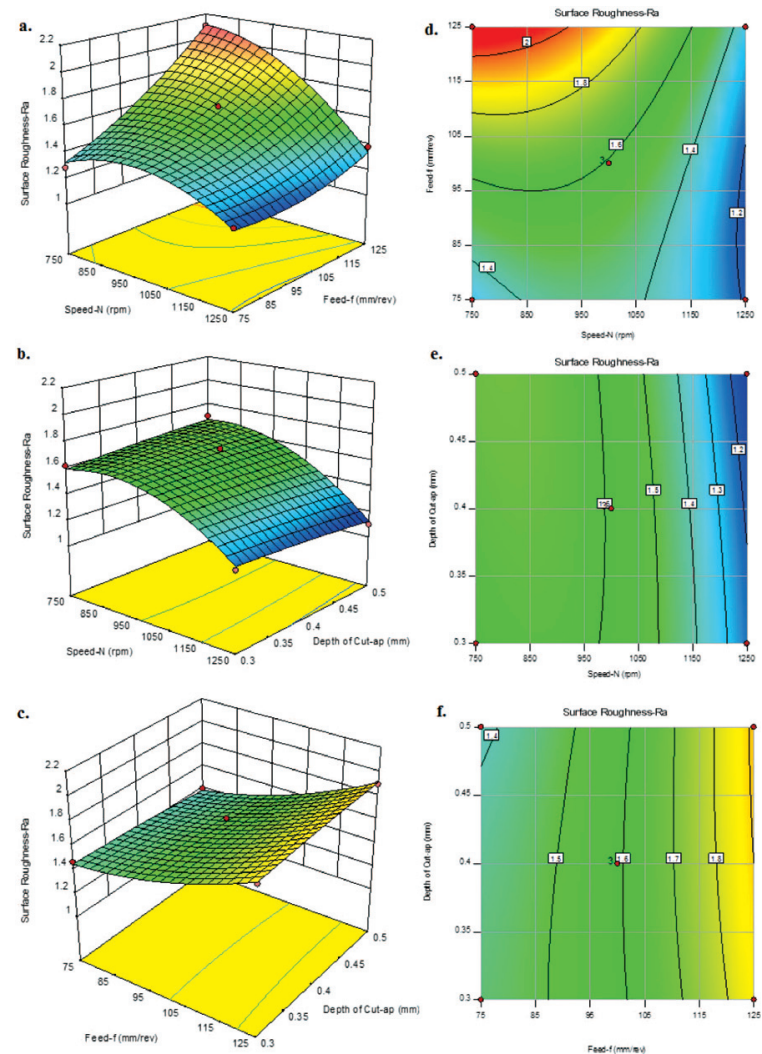

Figure 4: The 3D surface plot for the effects of machining parameters on the surface roughness 


\subsection{The surface and contour-plot analyses}

The RSM Box-Behnken experimental analysis was carried out in order to get better visibility and the analysis of the effects of machining parameters on the output response surface roughness the contour plot and 3D surface plots were drawn and shown in Figure 4. The contour plot and 3D surface plot of Figure $\mathbf{4 a}$ and $\mathbf{4 d}$ indicate the higher value of the speed at $1250 \mathrm{~min}^{-1}$ and a lower rate of feed of about $75 \mathrm{~mm} / \mathrm{rev}$ gives a better surface finish, while increasing the feed rate with a lower level of speed gives the highest value of the surface roughness. In Figure $\mathbf{4 b}$ and $\mathbf{4 e}$ we realize that there is no significant change while varying the depth of cut with respect to the speed, but the output response would be changed with respect to the variation of the speed values. Figure $\mathbf{4 c}$ and $\mathbf{4 f}$ represent the end milling process, while increasing feed rate gives predominantly effects on the surface roughness in terms of higher roughness values. The contour and $3 \mathrm{D}$ surface plots understand that the speed and feed rate have the highest influence on the output response. In this Box-Behnken experimental design the investigation provides the correlation between the machining parameters and the output response surface roughness in terms of the quadratic equation.

The quadratic response model provides the linear and interaction of the machining parameters $N, f$ and ap influencing the surface roughness were expressed in Equation (2) and it could be used to predict the surfaceroughness values for the anticipated machining parameters and displayed in Table 1. The RSM predicted values are closer to the experimental values and the higher level of speed at $1250 \mathrm{~min}^{-1}$, the medium level of
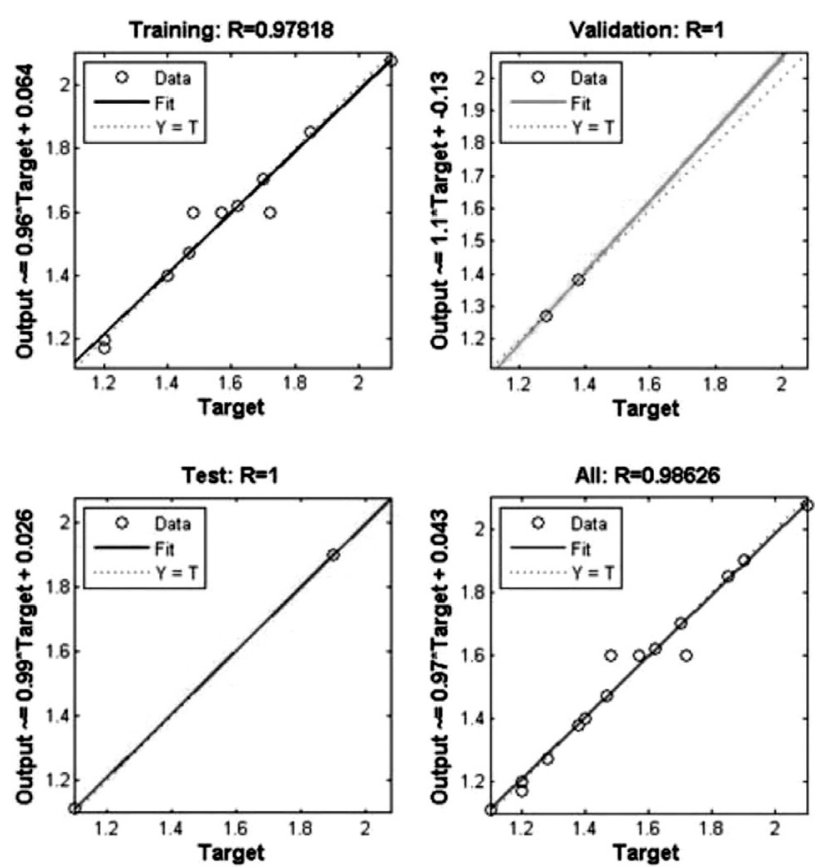

Figure 5: Artificial neural network: training and target regression model feed rate at $100 \mathrm{~mm} / \mathrm{rev}$ and the higher level of depth of cut at $0.5 \mathrm{~mm}$ provides a better surface finish of about $1.121 \mu \mathrm{m}$, it shows that the development and evaluation of the optimum machining parameters in the RSM technique proves the ability of optimization.

$R_{\mathrm{a}}=2.98+0.00797 \cdot N+0.0063 \cdot f+1.35 \cdot a p-$

$0.000003 \cdot N \cdot N+0.00012 \cdot f \cdot f-1 \cdot a p \cdot a p-0.00026 \cdot N \cdot f-$

$0.00280 \cdot N \cdot a p+0.12 \cdot f \cdot a p$

\subsection{The evolutionary optimization analysis}

The ANN model provides the performance of the network by an evaluation of the correlation coefficient between the output values and the target values for the given test data and shown in Figure 5. The evaluation of the network provides the correlation coefficient as 0.99 and it suggests that a good correlation has been obtained in between the experimental and predicted values for this ANN model. The average relative error in between the experimental and predicted values is $1.52 \%$; it confirms that the well-trained network has good accuracy in predicting the surface-roughness values. Figure 6 shows the error percentage chart of the predicted surface roughness values in terms of RSM, ANN and compared with experimental values and it resembles the average relative error found in terms of RSM and ANN models are $2.40 \%, 1.52 \%$, respectively. The ANN model provides the predicted values are very close to the experimental values and it suggests a better surface-finish value of $1.11 \mu \mathrm{m}$ with the optimal combination of machining parameters $\mathrm{N}$ at $1250 \mathrm{~min}^{-1}$, f at $100 \mathrm{~mm} / \mathrm{rev}$ and ap at $0.5 \mathrm{~mm}$. In this end milling optimization study the ANN model provides very close values of the output response to the experimental than the RSM model, and it proves the ability of training the model is more efficient.

The GA optimization has been carried out with coupling the result of ANN based on the genetic parameters above and the best fitness was attained for the given machining parameters ranges and shown in Figure 7. It shows that minimization of the surface roughness objective function has been achieved as $1.0926 \mu \mathrm{m}$ with the optimized values of the cutting

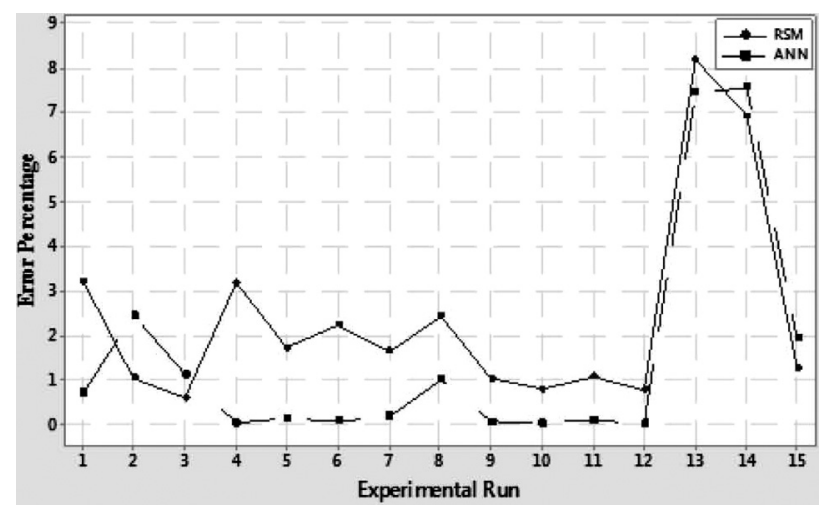

Figure 6: Error percentage chart of experimental vs. predicted values 


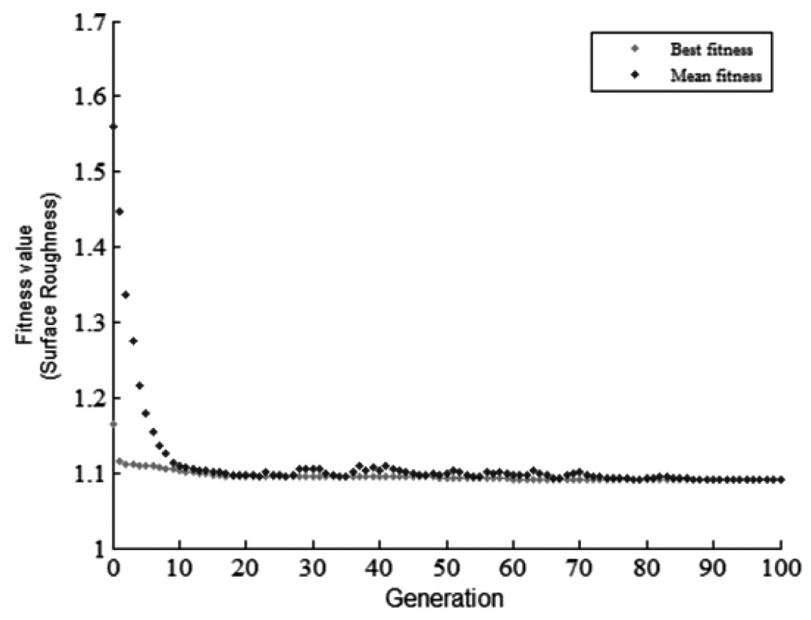

Figure 7: Best fitness of surface roughness on GA

parameters cutting speed $N$ at $1250 \mathrm{~min}^{-1}$, feed rate $f$ at $82.49 \mathrm{~mm} / \mathrm{rev}$ and depth of cut $\mathrm{ap}$ at $0.497 \mathrm{~mm}$. The confirmation test was carried out based on the recommendation from ANN and GA and the results shown in Table 3. It shows that the ANN and GA model brings good results with a low error percentage and both methods prove they are more effective in parameter optimization.

Table 3: Confirmation test

\begin{tabular}{|c|c|c|c|c|c|c|}
\hline \multicolumn{3}{|c|}{ Machining parameters } & \multicolumn{3}{|c|}{ Surface roughness } & \\
\hline \multirow{2}{*}{$\begin{array}{c}N \\
\left(\mathrm{~min}^{-1}\right)\end{array}$} & $\begin{array}{c}f \\
(\mathrm{~mm} / \mathrm{rev})\end{array}$ & $\begin{array}{c}\text { ap } \\
(\mathrm{mm})\end{array}$ & \multicolumn{2}{|c|}{ Predicted } & $\begin{array}{c}\text { Confir- } \\
\text { mation }\end{array}$ & Error \\
\hline 1250 & 100 & 0.5 & 1.11 & - & 1.15 & $3.6 \%$ \\
\hline 1250 & 82.49 & 0.49 & - & 1.09 & 1.12 & $2.75 \%$ \\
\hline
\end{tabular}

\section{CONCLUSIONS}

This experimental work suggests the application of evolutionary approaches to optimizing the machining parameters in the milling of the modern material magnesium alloy AZ91D. The following conclusions can be drawn:

- The Box-Behnken experimental design provides the better regression value of 96.76 ; it proves the most efficient design in the design of experiment. The outcome of the ANOVA suggests the cutting speed and feed rate have more of a contribution in this experiment, i.e., $36.02 \%$ and $38.43 \%$, respectively.

- The predicted values in the ANN model are very close to the experimental values and based on the error analysis, it indicates that the ANN model is a more effective approach than the RSM. The genetic algorithm suggests the minimal surface roughness as being $1.0926 \mu \mathrm{m}$.

- From this research it is clear that the ANN and GA model delivers the output responses with a lower error percentage and proves that they are more efficient methodologies for the optimization of advanced machining conditions.

\section{REFERENCES}

${ }^{1}$ H. Friedrich, S. Schumann, Research for a "New age of magnesium" in the automotive industry, Journal of Materials Processing Technology, 117 (2001), 276-281, doi:10.1016/S0924-0136(01)00780-4

${ }^{2}$ Eva María Rubio, María Villeta, Diego Carou, Adolfo Saa, Comparative analysis of sustainable cooling systems in intermittent turning of magnesium pieces, International Journal of Precision Engineering Manufacturing, 15 (2014) 5, 929-940, doi:10.1007/s12541-0140419-5

${ }^{3}$ I. Mukherjee, P. Kumar Ray, A review of optimization techniques in metal cutting processes, Computers \& Industrial Engineering, 50 (2006), 15-34, doi:10.1016/j.cie.2005.10.001

${ }^{4}$ A. J. Makadia, J.I. Nanavati, Optimisation of machining parameters for turning operations based on RSM, Measurement, 46 (2013), 1521-1529, doi:10.1016/j.measurement.2012.11.026

${ }^{5}$ K. Shi, D. Zhang, J. Ren, Optimization of process parameters for surface roughness and microhardness in dry milling of magnesium alloy using Taguchi with grey relational analysis, International Journal of Advanced Manufacturing Technology, 81 (2005), 645-65, doi:10.1007/s00170-015-7218-8

${ }^{6}$ N. Haq, P. Marimuthu, R. Jeyapaul, Multi response optimization of machining parameters of drilling $\mathrm{Al} / \mathrm{SiC}$ metal matrix composite using grey relational analysis in the Taguchi method, International Journal of Advanced Manufacturing Technology, 37 (2008), 250-255. doi:10.1007/s00170-007-0981-4

${ }^{7}$ A. M. Zain, H. Haron, S. Sharif, Prediction of surface roughness in the end milling machining using artificial neural network, Expert Systems with Applications, 37 (2010) 2, 1755-1768, doi:10.1016/ j.eswa.2009.07.033

${ }^{8}$ J. Kopac, P Krajnik, Robust design of flank milling parameters based on grey-Taguchi method, Journal of Material Processing Technology, 191 (2007) 1-3, 400-403

${ }^{9}$ J. A. Ghani, I. A. Choudhury, H. H. Hassan, Application of Taguchi method in the optimization of end milling parameters, Journal of Materials Processing Technology, 145 (2004), 84-92. doi:10.1016/ S0924-0136(03)00865-3

${ }^{10}$ J. S. Pang, M. N. M. Ansari, O. S. Zaroog, M. H. Ali, S. M. Sapuan, Taguchi design optimization of machining parameters on the $\mathrm{CNC}$ end milling process of halloysite nanotube with aluminium reinforced epoxy matrix (HNT/Al/Ep) hybrid composite, Housing and Building National Research Center Journal, 10 (2014), 138-144. doi:10.1016/j.hbrcj.2013.09.007

${ }^{11}$ E. Kuram, B. Ozcelik, Multi-objective optimization using Taguchi based grey relational analysis for micro-milling of Al 7075 material with ball nose end mill, Measurement, 46 (2013), 1849-1864, doi:10.1016/j.measurement.2013.02.002

${ }^{12}$ Montgomery D C., Design and analysis of experiments, John Wiley and Sons, New York, 1991

${ }^{13}$ P. J Ross, Taguchi Techniques for Quality Engineering, Tata Mc Graw Hill, (2005)

${ }^{14}$ R. H. Myers, D. C. Montgomery, C. M. Anderson-Cook, Response Surface Methodology: Process and Product Optimization Using Designed Experiments, John Wiley \& Sons, 2016

${ }^{15}$ I. Asiltürk, S. Neseli, Multi response optimization of CNC turning parameters via Taguchi method-based response surface analysis, Measurement, 45 (2012), 785-794, doi:10.1016/j.measurement. 2011.12.004

${ }^{16} \mathrm{H}$. El-Mounayri, H. Kishawy, J. Briceno, Optimization of CNC ball end milling: a neural network-based model, Journal of Materials Processing Technology, 166 (2005) 1, 50-62, doi:10.1016/j.jmatprotec.2004.07.097 


\section{PRADEEPKUMAR et al.: EVALUATION OF THE SURFACE INTEGRITY IN THE MILLING OF A MAGNESIUM ALLOY ...}

${ }^{17}$ R. K. Dutta, S. Paul, A. B. Chattopadhyay, The efficacy of back propagation neural network with delta bar delta learning in predicting the wear of carbide inserts in face milling, International Journal of Advanced Manufacturing Technology, 31 (2006) 5-6, 434-442, doi:10.1007/s00170-005-0230-7

${ }^{18}$ N. R. J. Hynes, R. Kumar, J. A. J. Sujana, Optimum bushing length in thermal drilling of galvanized steel using artificial neural network coupled with genetic algorithm, Mater. Tehnol., 51 (2017) 5, 813, doi:10.17222/mit.2016.290

${ }^{19}$ H. El-Mounayri, J. F. Briceno, M. Gadallah, A new artificial neural network approach to modeling ball-end milling, International Journa of Advanced Manufacturing Technology, 47 (2010) 5-8, 527-534, doi:10.1007/s00170-009-2217-2
${ }^{20}$ M. Durairaja, D. Sudharsunb, N. Swamynathan, Analysis of Process Parameters in Wire EDM with Stainless Steel using Single Objective Taguchi Method and Multi Objective Grey Relational Grade, Procedia Engineering, 64 (2013), 868-877, doi:10.1016/j.proeng. 2013.09.163

${ }^{21}$ F. Cus, J. Balic, Optimization of cutting process by GA approach, Robotics and Computer Integrated Manufacturing, 19 (2003), 113-121, doi:10.1016/S0736-5845(02)00068-6

${ }^{22}$ R. Q. Sardin, P. Reis J., P. Davim, Multi-objective optimization of cutting parameters for drilling laminate composite materials by using GA, Composites Science and Technology, 66 (2006), 3083-3088, doi:10.1016/j.compscitech.2006.05.003

${ }^{23}$ K. Deb, Multiobjective Optimization Using Evolutionary Algorithms, New York: Wiley (2001) 